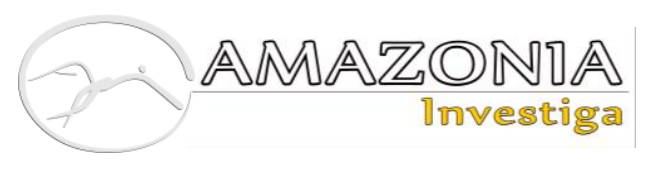

DOI: https://doi.org/10.34069/AI/2022.49.01.29

How to Cite:

Kravchenko, N., Prokopchuk, M., Pozhar, A., Kozyarevych-Zozulya, L., \& Rozhkov, Y. (2022). Illocutionary Pragmatic Adaptation Challenge: Ukrainian Translations of English-language Soft Law Texts. Amazonia Investiga, 11(49), 267-276. https://doi.org/10.34069/AI/2022.49.01.29

\title{
Illocutionary Pragmatic Adaptation Challenge: Ukrainian Translations of English-language Soft Law Texts
}

\section{Проблема іллокутивної прагматичної адаптації в українських перекладах англомовних правових текстів м'якого права}

Received: November 27, 2021

Accepted: January 4, 2022

Written by:

Nataliia Kravchenko ${ }^{114}$

https://orcid.org/0000-0002-4190-0924

Mariia Prokopchuk ${ }^{115}$

https://orcid.org/0000-0002-8248-0479

Anastasiia Pozhar ${ }^{116}$

https://orcid.org/0000-0001-9821-0740

Liana Kozyarevych-Zozulya ${ }^{117}$

https://orcid.org/0000-0003-1894-7713

Yurii Rozhkov ${ }^{118}$

https://orcid.org/0000-0002-6830-9130

\begin{abstract}
The article introduces the concept of illocutionary pragmatic adaptation (IPA) as a local translation adaptation aimed at replacing, de-intensifying or strengthening the modality in Ukrainian translations of the English-language soft law texts. The idea of IPA is based on the premises of illocutionary forces-modality correlation, their graded nature added by the concept of pragmatic translation adaptation, its types, criteria, and strategies. Basic IPA means include shall-associated transformations aimed at adaptation to a softer law and should-associated IPA to a harder law. The omission of shall in the Ukrainian translations results in transforming explicit directives into two-intentional assertives, effecting the replacement of obligative modality by an epistemic belief that the rule should be followed instead of the requirement for the rule
\end{abstract}

Анотація

\footnotetext{
${ }^{114}$ Doctor of Philology, Full Professor at Department of Translation Studies, Kyiv National Linguistic University, Ukraine. Her professional and research interests lie in the area of translation and English literature, Discourse Analysis, Pragmatics, Cognitive Linguistics.

115 Candidate of Pedagogical Sciences, a senior lecturer of English language and Communication Department, Borys Grinchenko Kyiv University, Ukraine. Her research focuses on Language Learning and Acquisition, Second Language Acquisition, Information and Communication Technology Implementation into the Educational Process.

${ }^{116}$ Candidate of Philological Sciences, a senior lecturer of the Department of Phonetics, Spoken and Written English, Kyiv National Linguistic University, Ukraine. Her professional and research interests lie in the area of pragmatics, lexical semantics, discourseanalysis, nonverbal semiotics, pragma semantic analysis, speech acts analysis.

${ }^{117}$ Candidate of Philological Sciences, associate professor of Kyiv National Linguistic University, Ukraine. Her Scientific interests include pragmatics, theory of communication, nonverbal semiotics, linguistics of emotions.

${ }^{118}$ Candidate of Philological Science, a senior lecturer of the Department of Romance and Germanic Languages and Translation at National University of Life and Environmental Sciences of Ukraine. His research interests include Cognitive Linguistics, Frame Semantics, Corpus Linguistics, and Specialized Terminology.
} 
observation. Replacing the modal verb of the recommendation should with the verb of obligation "повинні» (must) leads to the transformation of modality of recommendation into an obligative one based on strengthening the directive illocutionary force. The paper has identified three factors of IPA: (1) genre-related, which determines the target text adaptation either to the softer or harder genres of the source text; (2) a discursive space of soft law core values effecting IPA with a decrease in directive illocutionary force and obligative modality; (3) the factor of the local context.

Key words: basic devices, deontic modality, illocutionary force, pragmatic adaptation; soft law.

\section{Introduction}

The article introduces the concept of illocutionary pragmatic adaptation (IPA) in translation as a type of local pragmatic adaptation of the source text based on transformation of illocutionary forces and their associated modality. The analysis bases on the EnglishUkrainian translations of international soft law a set of rules and guidelines that consolidates mainly political obligations of states, binding at the discretion of the party (Abbott \& Snidal, 2000; Hillgenberg, 1999).

The relevance of the article is that it contributes to the problem of pragmatic adaptation, which is the constant research challenge in translation studies. For the first time the problem is solved on the basis of international legal texts, which, due to their specificity, exclude intercultural asymmetry as a traditional factor of translation adaptation.

Assumed from the existing theoretical premises of illocutionary force graduated strength and different-scaled modality meanings, the paper advances the hypothesis that the transformationsbased change in the type of speech act or its intensity affects either the replacement of deontic modality by epistemic, or the change of the deontic modality scale. Such illocutionary transformations are considered by the article as a українських перекладах має своїм результатом трансформацію експліцитних директивів у двокомпонентні за своєю інтенцією ассертиви, що впливає на заміну облітивної модальності на епістемічну впевненість у тому, що правило має бути виконане - замість вимоги щодо його виконання. Заміна модального дієслова рекомендаціï "should" дієсловом зобов'язання "must" призводить до перетворення модальності рекомендації на облігативну модальність, що базується на посиленні директивної іллокутивної сили. Ідентифіковані три фактори ІПА: 1) жанровий, який визначає адаптацію цільового тексту або до більш м'яких, або до більш жорстких жанрів вихідного тексту; 2) дискурсивний простір основних цінностей м'якого права, який впливає на ІПА із деінтенсифікацією директивної іллокутивної сили та облігативної модальності; 3) локальний контекст.

Ключові слова: базисні засоби, деонтична модальність, іллокутивна сила, прагматична адаптація, м'яке право.

pragmatic adaptation to soft law in general or to its specific genres, different in their legal binding force.

The purpose of the article is to substantiate the illocutionary pragmatic adaptation of Englishlanguage soft law texts in Ukrainian translations from the point of view of its factors and core devices.

Of particular importance for this study is the approach to the adaptation by Yves Gambier, who believes that even if the translator is forbidden to work with the source text with a certain "freedom" of action (as, for example, in legal or other institutional texts), adaptation still happens (Gambier \& Gottlieb, 2001, p. 35). The second observation, relevant to our research, belongs to Vinay and Darbelnet (1958/1972, p. 54), and concerns translations of international texts, which must not be just the bureaucratic translations, «that give correct information and zero aspiration; (...) it is a matter of encouraging citizens to be involved in supra-national politics». These ideas meet up with modern "calls for translations to act as events in themselves (Pym, 2012, pp. 122-123; Venuti, 2012, pp. 184-186; Nord, 2014). 


\section{AMAZONIA
Trvestiga}

Considering the purpose of this study, its theoretical framework encompasses three research vectors, integrated to substantiate the research hypothesis.

\section{Literature review}

The problem of speech acts correlation with modal meanings is quite problematic and poorly explored. The solution to this problem is hampered by the lack of unanimity in linguistics regarding the number and types of modal categories, which vary from two to seven classes according to different researchers (Hegarty, 2016; Nuyts, 2016; Palmer, 1986; Quirk et al., 1985).

Despite some terminological differences, researchers have achieved a certain unanimity regarding the classes of modality: Alethic (modes of truth), Epistemic (modes of knowing), Deontic (modes of obligation), Existential (modes of existence) and Teleological (modes of purpose). In addition to these types, Palmer (1986) differentiates the modality of desire (Volitive modality), and quantificational modality. Kai von Fintel (2006) distinguishes the bouletic modality that correlates with the modality of desire, and dynamic modality.

Not less relevant in modern linguistics the issue of the modality-illocutionary force correlation -

Table 1.

Modality, illocutionary forces, and the grammatical means: interface for directives and assertives.

\begin{tabular}{|c|c|c|c|}
\hline $\begin{array}{l}\text { Type of the } \\
\text { utterance }\end{array}$ & $\begin{array}{l}\text { Illocutionary force } \\
\text { and type of the } \\
\text { speech act }\end{array}$ & $\begin{array}{l}\text { Type of the } \\
\text { sentence }\end{array}$ & Modality \\
\hline Statement & $\begin{array}{l}\text { Constatative } \\
\text { illocutionary } \\
\text { function; } \\
\text { assertive speech acts }\end{array}$ & Declarative & $\begin{array}{l}\text { Eepithemic modality of possibility / } \\
\text { necessity: } \\
\text { (a) judgements (apodictic, conditional, } \\
\text { hypothetical, consessional, purposive, } \\
\text { speculative, necessitative, assumptive, } \\
\text { etc.); } \\
\text { (b) evidentials (quotative and visual) }\end{array}$ \\
\hline Mand / Question & $\begin{array}{l}\text { Directive } \\
\text { illocutionary force }\end{array}$ & $\begin{array}{l}\text { Imperative } \\
\text { Interrogative }\end{array}$ & $\begin{array}{l}\text { Deontic modality (permission / } \\
\text { obligation): } \\
\text { compulsives, commands, demands, } \\
\text { advices, invitations, permissions, } \\
\text { prohibitions, requests, wishes, } \\
\text { permissions, } \\
\text { warning, recommendation, etc. }\end{array}$ \\
\hline
\end{tabular}

The correlation between the utterance type, the sentence type and illocutionary force is less obvious for commissives. However, it is indisputable to refer the commissive illocution to the subclass of deontic modality. In particular, considering that speech acts serve as a mediating link between grammatical means and forms of modality, on the one hand, and of the communicative and, more broadly, the discursive function of modal meanings, on the other hand. In this regard, John Lyons notes that the theory of speech acts is conceptually positioned between communicative function and modality as it provides a general framework for "the discussion of syntactic and semantic distinctions that linguists have traditionally described in terms of mood and modality" (Lyons, 1977, p. 725).

In speech acts theory the correlation of modal meanings of utterances with the structure of speech acts was first noted by J. Searle (1983), based on the concepts of "proposition" and "propositional attitude" (modal frame). The "division" of an utterance into a proposition and a modal frame was then introduced by A. Vezhbitskaya (2015) into semantics and is used today to determine the modal meanings of utterances.

The correlations between modality, illocutionary forces, and grammatical means of their expression in relation to assertives and directives are shown in table one (Palmer, 1986, 23-26; Lyons, 1977, 725-849). 
A definite contribution to the problem of the illocution-modality correlation was made, on the one hand, by studies of the phenomena of mitigation / reinforcement from the point of view of "degrees of strength" of illocutionary force, and, on the other hand, the concept of different modal strength (Palmer, 1986, pp. 57-58; Quirk, et al., 1985)

In the same vein, in functional grammar, modal dimensions, which distinguish types of modal expressions, are presented precisely as paradigms organized on the principle of scale for example, the scale-paradigm of "probability" (Halliday, 2004, p. 148).

Considering the above, the paper assumes that a change either in the type of act or in its illocutionary intensity directly affects the characteristics of modalities of discourse structured by such acts. It is hypothesized that transformation of speech acts illocutionary points or their intensity in the target text compared to the source text is a kind of pragmatic adaptation of modality. With that in mind, one of the theoretical premises of the work encompasses the studies, focused on the issue of translation pragmatic adaptation.

Adaptation, which has always aroused scientific interest in translation studies (Baker \& Saldanha, 2011), are differentiated into local and global as well as pragmatic and sociocultural types (Baker $\&$ Saldanha, 2011). Given the peculiarities of the international legal text as the manifestation of a collective will of the states-parties to the document, the translation of such a mutual will, aimed at harmonization of international conduct, "prohibits" the reconstruction of the whole text or its global adaptation.

However, the translator can consciously or unconsciously (Raw, 2012, p. 26) adapt fragments of the text to different degrees of commissive, directive, etc. deontic modalities according to the peculiarities of soft law genres. In texts under consideration there will be a local adaptation that applies to fragments of the text and has "very limited impact on the target text as a whole" (Baker \& Saldanha, 2011). For the same reasons, the adaptation of legal text cannot be sociocultural, but only pragmatic, adapted "to the needs of the target language audience" (Neubert, 1968 , p. 34) and providing equivalent communicative effect. Intercultural differences in international legal texts are manifested only at the level of interlingual asymmetry of the language systems.
Among the criteria that determine pragmatic adaptation for more details see Halliday (1964, p. 35; Neubert, 1968, p. 56), this article highlights the text register parameters. i.e. the criterion of the "field (Van Leeuwen, 1993), which, in our case, deals with different genres of soft law varying in degrees of their binding force.

Among the numerous strategies of pragmatic adaptation (Chesterman \& Wagner, 2002, pp. 60-63) the most important within the framework of this research is the strategy of 'illocutionary change' directly related to the illocutionary subtype of adaptation, which is associated with the transformation of the soft law modality and under consideration in this paper.

\section{Methodology}

To achieve the purpose, the paper uses a set of complimentary methods of analysis, including speech acts explanatory tools, the elements of discourse analysis and pre-translational text analysis. Speech acts analysis (Kravchenko, 2017, 2017a; Sadock, 2004; Searle, 1975, $1975 \mathrm{a}$ ), is related to (a) identification of the type of speech act, adaptable in translation, as well as illocutionary force indicating devices, which transformation results in a change in illocutionary point / its intensity and associating modality meanings, (b) identification of compound illocutionary meanings of direct and indirect speech acts.

The research partially employs a pre-translation analysis of international documents based on a discursive model of translation that involves the interrelated modules of (a) a harmonized value opposition between "common" and "sovereign" (Kravchenko, Pasternak, 2020); (b) the discourse addresser / addressee, embodied in the metonymic nomination "parties of the document"; (c) the translator as an intermediate system, which is the addressee of the original text and the addresser of the translated text; (d) extratextual factors; (e) the text semiospheres - both unifying (international documents) and separating (the parties domestic legislation).

The corpus of the analyzed texts includes nine documents of international soft law in English and their translated versions in Ukrainian. The data selection criteria included markers of IPM variation in the source and target texts - modal verbs, which transformation in translation results in change / de-intensification / intensification directive illocutionary forces and associated modality meanings. 


\section{AMAZONDA
1mvestiga}

The analysis is carried out in three consecutive stages:

1) analysis of speech acts associated with deontic obligative modality in the source and target texts - to identify lexical transformations of modal verbs illocutionary force indicating devices;

2) justification of such transformations as the key means of modality adaptation in soft law texts, triggering de-intensification or strengthening of illocutionary force;

3) identification of the factors of illocutionary pragmatic adaptation of modality.

\section{Results and Discussion}

Despite the minimum interference of the translator of international legal documents in the source text and the maximum "depersonalization" of the translation, the corpus of soft law texts evidences the use of pragmatically marked translation adaptations. In the texts of the soft law any changes, even insignificant ones, of the scale of deontic modality, correlating with the weakening or strengthening of the illocutionary force of directives acts, significantly affect the document legal force.

According to the Principles and rules for the structure and drafting of ISO and IEC documents (ISO, 2021). "shall" indicates an obligation or a legal requirement (see Table 3 - Requirement). The same writing standards are postulated in English Style Guide (2021), provided for authors and translators in the European Commission. In particular, par. 10.24. of the Guide "Positive imperative" states: "To impose an obligation or a requirement, EU legislation uses shall” (English Style Guide, 2021, p. 55).

For example, in (1) according to the above rules, the performative verb shall, which introduces the performative part of the directive and functions as an operator of obligative deontic modality, is not only reproduced in the Ukrainian translation, but it is also repeated twice, intensifying directive illocutionary force.

1) States shall therefore respect international law providing protection for the environment in times of armed conflict and cooperate in its further development, as necessary (principle 25, Rio Declaration on Environment and Development, United Nations (1992)) - Тому держави повинні поважати міжнародне право, яке забезпечує захист навколишнього середовища під час збройних конфліктів, i повинні співпрацювати, при необхідності, у справі його подальшого розвитку (States must / should respect international law, which ensures the protection of the environment during armed conflicts, and must / should cooperate, if necessary, in its further development).

At the same time, soft law translations into Ukrainian evidence that only $10 \%$ of the target texts is rendered by means of preserving shall and explicit directive illocutionary force conveyed by it. The established translation tradition is the verbal phrase transformation with modals shall / shall not into the notional verb in present tense with omission of a modal shall, which results in transforming the explicit directives into two-intentional assertive with the implicit directive illocution as one of the illocutionary points along with assertive intention. Accordingly, the directive modality associated with the need to comply with regulatory rules is transformed into an epistemic modality of necessity (see Table 1) with an emphasis neither on obligation nor even recommendation, but on the belief that the rule must be followed. As a result, the translationbound epistemic meaning weakens deontic obligative modality of the document fragment, as shown in (2):

2) All Parties, taking into account their common but differentiated responsibilities and their specific national and regional development priorities, objectives and circumstances, shall (performative part): (a) Develop, periodically update, publish and make available to the Conference of the Parties (...)national inventories (propositional part) (article 4.1 (a), United Nations Framework Convention on Climate Change, United Nations (1992)). - Yci Сторони, враховуючи свою спільну, але диферениійовану відповідальність $і$ свої конкретні національні $i$ регіональні пріоритети, ичілі $і$ умови розвитку: а) розробляють, періодично поновлюють, публікують, $i$ надають Конференції Сторін національні кадастри (All Parties ... develop, periodically update, publish...).

In contrast to the original text where the modal operator shall explicitly indicate obligative modality and the performative (illocutionary) clause of the directive, the Ukrainian translation represents only a propositional part, and, accordingly, the directive illocutionary force is 
implicated as one of the illocutionary forces of the assertive-framed two-intentional act.

The same illocutionary transformations resulted in a pragmatic adaptation of the obligative modality fragment to epistemic modality expressed by two-intentional assertive is observed in (3) and (4).

3) In this context the Parties shall inter alia provide adequate opportunities for teacher training and access to textbooks and facilitate contacts among students and teachers of different communities (12.2, Framework Convention for the Protection of National Minorities) - (...) Сторони забезпечують належні можливості (...) та сприяють...

4) Each of these Parties shall adopt national policies and take corresponding measures on the mitigation of climate change (article 4 (2a), United Nations Framework Convention on Climate Change, United Nations (1992)) - кожна 3 цих Сторін проводить національну політику i застосовує відповідні заходи у пом'якшенні наслідків зміни клімату.

In the target fragments, the performative parts of directives are rendered as provide opportunities in (3) and conducts national policy in (4). That results in assertive acts that combine illocutionary points of confidence in what it is communicated and implicit recommendation. So, one of the illocutionary points in assertive act remains directive, but with a significantly decreased degree of strength of obligative illocutionary force.

Similar local pragmatic adaptation of the text fragment to a softer law is identified in the speech acts, introduced by "week" directive, represented by the verb phrase in passive as is observed in the fragment (5):

5) In order to protect the environment, the precautionary approach shall be widely applied by States according to their capabilities (Principle 15 of the Rio Declaration on Environment and Development, United Nations (1992)) - (...) держави відповідно до своїх можливостей широко застосовують принцип прийняття запобіжних заходів (States, according to their capabilities widely apply the principle of precautionary measures)
In the translated utterance, the "week" directive in passive is transformed into an assertive speech act due the omission of shall that affects the scale of the obligative modality since the "weak" deontic modality of the obligation is substituted by epistemic modality. The adaptation of modality to softer law is genre-conditioned, since the genre of the Declaration is an instrument of expressing the intention of states, which, however, does not have binding legal force. An additional local adaptation factor is presented in the original texts by a hedging structure according to their capabilities, which provides for the possibility of variative application of rules.

At the same time, the transformation of the passive construction in the original text into an active one partially compensates them for the loss of directive modality by increasing the degree of the subject's responsibility for the actions performed (at the formal level, this is conveyed by placing the subject of the action in the syntactical position of the phrasal subject: держави (...) широко застосовують принцип прийняття запобіжних заходів (states ... widely apply the principle of precautionary measures) instead of: the precautionary approach shall be widely applied by States in original text.

The paper identified three main factors of illocutionary pragmatic adaptation: genrerelated; discursive; the local contextual and a combination of factors.

In particular, in (2) and (5), the local contextual factor of adaptation bases on parenthetical phrase-hedge that functions as a kind of reduced exemption clause weakening the obligative modality: taking into account their common but differentiated responsibilities and their specific national and regional development priorities, objectives and circumstances; according to their capabilities. Other identified hedges involve as far as possible, if there is sufficient demand, where appropriate, where necessary, where relevant, as appropriate, States Parties shall take all measures they deem appropriate, etc. as exemplified by (6):

6) In the areas inhabited by persons belonging to national minorities traditionally or in substantial numbers, if there is sufficient demand, the Parties shall endeavour to ensure, as far as possible and within the framework of their education systems, that persons belonging to those minorities have adequate opportunities for being taught the 


\section{$\mathbb{A} M \mathbb{A Z O N D \mathbb { A }}$}

minority language (article 10 (2), Framework Convention for the Protection of National Minorities) - (...) на прохання таких осіб $i$ якщчо таке прохання відповідає реальним потребам, Сторони намагаються забезпечити (are trying to provide) по можливості (...).

In (6) the transformation of shall endeavor_into are trying with the omission of the modal shall affects the modal frame of the utterance as it loses its illocutionary force indicating device of the explicit directive, enquiring the structural and illocutionary properties of the assertive. The paper assumes that adaptation to epistemic modality of the softer law is triggered here by the local context of the source fragment, which contains three hedges stipulating the conditions for fulfilling the requirements: if there is sufficient demand; as far as possible and within the framework of their education systems.

The hedges-derogations may trigger the illocutionary pragmatic adaptation as they convey both permissive modality (imply the possibility of the requiments non-compliance) and dynamic modality meanings (the execution of an action under certain circumstances). Accordingly, the scale of alternativity increases and, on the contrary, the degree of the document binding force decreases.

The paper concludes that the pragmatic adaptation, caused by its local contextual triggers, adapts the performative part of the directive act (omission of shall) to the markers of softer deontic modality - hedges contained in its propositional part.

In addition to the parenthetical hedges, the local trigger of adaptation to a softer law, expanding a discretionary power of the Parties, also involve "without prejudice" clauses; metonymic nominations of "sovereign power"; idiomatic references to "public safety", "morals", "cultural identity" and other "implicated intertextuality devices" (Kravchenko \& Zhykharieva, 2020) to the texts of domestic legislation, scaling down the directive modality.

On the other hand, the means of the local context may also trigger the vice versa adaptation of the utterance to the harder obligative modality, with the replacement of may in negative structure by must as in (7).

7) These rights and freedoms may in no case be exercised contrary to the purposes and principles of the United Nations (article 26,
Universal Declaration of Human Rights, United Nations Human Rights, (1948)) Здійснення цих прав і свобод ні в якому разі не повинно суперечити ... (The exercise of these rights and freedoms must in no case be contrary...).

The adverbial phrase in no case, used to negate the verb and denote the prohibition locally intensifies the obligatory modality of the act, triggering the replacement of the modal verb of permissive semantics by modal must that conveys strong requirement.

In addition to local contextual factors, the criteria of illocutionary pragmatic adaptation also involve genre and discursive factors.

Genre adaptation is possible due to the variation of soft law documents along the scale of obligative deontic modality - from such soft genres as Declarations, Principles, Rules, Appeals, etc., which have minimal binding force, - to the stricter law of the Framework Convention - the genre closest to compulsory law. Correspondently, the paper reveals two types of genre adaptation, incl.: (a) to a "softer" genre of the source text, which results in shall omission, de-intensification of directive illocutionary force and obligative modality and shift to epistemic modality; (b) to a harder law, which results in the substitution of the modal verb of recommendation should by the obligative verb "повинні» (must), triggering the intensification of the directive illocutionary force and obligative modality.

The first type of genres, characterized by the features of genre hybridity, combining the characteristics of legal and political discourses, I.I. Lukashuk classifies a "soft law" of illegal international norms (1997, c. 124). Accordingly, when translating such documents, it is possible to adapt them to the soft "declarative" modality of the genres they represent as in (8):

8) States and people shall cooperate in good faith and in a spirit of partnership in the fulfilment of the principles embodied in this Declaration (principle 27, Rio Declaration on Environment and Development, United Nations, (1992)) - Держави і народи cniвпраиюють (cooperate) у дусі доброї волі і партнерства у виконанні принципів, втілених у цій Декларації (...).

And, vice versa, the genre criterion of adaptation may be engaged if the translation adapts to the Framework Convention "as an umbrella 
document which lays down the principles, objectives and the rules of governance of the treaty regime. (Framework Convention Concept, p. 1). The framework conventions refer to soft law because they form a special type of international law - "general" norms and principles that are used in international treaties (Lukashuk 1997, p. 124).

In this regard, a typical example of pragmatic adaptation to a harder law is the substitution of the modal verb of recommendation should with the verb of obligation повинні (must):

9) The Parties should cooperate to promote a supportive and open international economic system (...) (article 3 (5), United Nations Framework Convention on Climate Change, United Nations (1992)) - Сторони повиннi співробітничати (must cooperate) 3 метою встановлення сприятливої i відкритої міжнародної економічної системи,

In accordance with the Principles and Rules of the International Organization for Standardization (ISO) (2021), "should" is used in documents to express a recommendation (Table 4 - Recommendation). As a performative verb should expresses a modality of recommendation as a subcategory of obligatory deontic modality that correlates with directive speech acts, but differs in less directive strength compared to obligations or requirements.

Approximately 75 percent of the Ukrainian translations are carried out in compliance with the above standards - with preserving the recommendation modality, conveyed by impersonal structures слід та необхідно (it is needed, it is necessary). However, approximately 25 translations transform the recommendation modality into the modality of the obligation that relies on the intensification of the directive illocutionary force and results in the pragmatic adaptation to a harder law.

The paper revealed that the genre factor in the case of adaptation to a harder law is more efficient than the criterion of the local context, as shown by (10), where hedges, weakening the recommendatory modality in the source text, does not prevent its adaptation to the genre of the Framework Convention:

10) Without prejudice to the sovereign right of the Parties to determine and establish their taxation policies, each Party should take account of its national health objectives concerning tobacco control (...) (article 6 (2), WHO Framework Convention on Tobacco Control, WHO (2003)).

Без шкоди для суверенного права Сторін \begin{tabular}{lrr} 
визначати & $\check{u}$ \\
\hline встановлювати
\end{tabular} оподатковування, кожна Сторона повинна (must)

враховувати свої національні ичілі в галузі охорони здоров'я, які стосуються боротьби проти тютюну (...).

The third identified factor of illocutionary pragmatic adaptation is discursive - determined by features of "soft law" as a whole discursive semiotic space constituted by the concepts of "recommendation", "desirability", "possibility". In this vein, the adaptation is carried out in accordance with the "genre semiosphere" of soft law that integrates the most general discursive features - formal, conceptual, semantic, etc., of all genres of such law (Kravchenko, 2006).

The discourse criterion is involved in the translated fragments adaptation to a softer law with the de-intensification of obligative modality and the transformation of directives into assertives (that is, transformation with the omission of shall). This discursive factor can, in particular, explain the transformation of an obligative deontic modality into an epistemic one in the genre of the Framework Convention as in (11):

11) Each Party shall develop, implement, periodically update and review comprehensive multisectoral national tobacco control strategies, plans and programs in accordance with this Convention and the protocols to which it is a Party (article 5 (1), WHO Framework Convention on Tobacco Control, WHO (2003)) - Кожна Сторона розробляє, здійснює, періодично оновлюе та переглядає (develop, implement, periodically update and review) всебічні багатосекторальні національні стратегії, плани й програми 3 боротьби проти тютюну.

Modal verbs omission or replacing-illocutionary force markers, the article qualifies as the basic means of pragmatic adaptation, since they adapt the modality of speech acts either to the characteristics of soft law, or to one of its genres, which differ in their legal binding, or to local contextual triggers. 


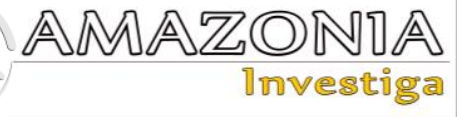

Conclusions

The article introduces the concept of illocutionary pragmatic adaptation as a kind of local translation adaptation aimed at changing, de-intensifying or strengthening the modality scale in the target Ukrainian text in comparison with the original soft law text in English. The notion of IPA is based on the interface of the theoretical premises about illocutionary forcemodality correlation and their scaled nature, added by the idea of pragmatic translation adaptation, its types, criteria, and strategies. Based on a compound research method, consistently applied in three stages of investigation, the paper has reached principal findings about basic means of IPA and its main factors.

Basic means include transformation of the verbal group, containing modals shall and should as illocutionary force markers. The omission of shall in the Ukrainian translations either in active or in passive results in transforming the explicit directives into two-intentional assertive that combine illocutionary points of confidence in what is communicated (assertive illocutionary act) with an implicit recommendation (the deintensified directive illocutionary act). Illocutionary transformations result in replacement of obligative modality with epistemic modality with an emphasis not on the demand but on the belief that the rule must be complied. Shall-associated transformations represent the adaptation to a softer law.

Another basic means of IPA includes the substitution of the modal verb of recommendation should with the verb of obligation "повинні» (must), which results in the recommendation modality transformation into obligative modality based on intensification of the directive illocutionary force. Shouldassociated transformations represent the adaptation to a harder law.

Second. The paper identified three main factors of illocutionary pragmatic adaptation: genrerelated; discursive; the local context of the translated fragment.

Genre-related factors determine IPA either to the soft (declarative) genre of the source text, which results in omission shall, transformation of directives into assertive, and a shift to epistemic modality, or to a harder law - with substitution of the modality of recommendation, conveyed by should by the strong obligative modality, expressed by “повинні» (must), intensifying the directive illocutionary force.

The discursive factor of the discursive semiotic space, structured by normative values of "recommendation", "desirability", "possibility", determine adaptation towards softening the norms (based on the directives into assertive transformation) and obligative deontic modality into an epistemic one in the genre of the Framework Convention.

The local context triggers of IPA to softer law are based on parenthetical phrase-hedges that function as a reduced exemption clause, which expand a discretionary power of the participating States and weaken the obligative modality, which results in omission of shall in translation.

The local context triggers IPA to harder law occurs in isolated cases and it is based on prohibition clause to emphasize that something must not happen.

\section{Bibliographic references}

Abbott, K. W., \& Snidal, D. (2000). Hard and Soft Law in International Governance. International Organization, V54 (3), 421-456. Retrieved Sept 20 from: Hard and Soft Law in International Governance (eastlaw.net)

Baker, M., \& Saldanha, G. (2011). Routledge Encyclopedia of Translation Studies. New York: Routledge.

Chesterman, A., \& Wagner, E. (2002). Can theory help translators? A dialogue between the ivory tower and the wordface. Manchester: St. Jerome Publishing.

English Style Guide (2021). A handbook for authors and translators in the European Commission. European Commission. Eighth edition: January 2016. Retrieved Sept 10 from: English Style Guide (europa.eu)

Framework Convention for the Protection of National Minorities (1995). Retrieved Sept 25 from: https://rm.coe.int/16800c10cf*

Gambier, Y., \& Gottlieb, H. (2001). Multimedia translation concepts, practices, and research (pp. vii-xx). Amsterdam: John Benjamins.

Halliday, M. (2004). An introduction to functional grammar (3rd ed.). London: Edward Arnold.

Halliday, M. (1964). Comparison and translation, in M. A. K. Halliday, M. McIntosh and P. Strevens, The linguistic sciences and language teaching. London: Longman.

Hegarty, M. (2016). Modality and propositional attitudes. Cambridge: Cambridge University Press. Retrieved from https://www.cambridge.org/core/books/modalit $\mathrm{y}$-and-propositional- 
attitudes/F01FC0CD9721906E7079EE3556EC 0680

Hillgenberg, H. (1999). A Fresh Look at Soft Law. European Journal of International Law, No 3, p. 499-515.

ISO (2021). Principles and rules for the structure and drafting of ISO and IEC documents Retrieved Sept 5 from: https://www.iso.org/sites/directives/current/par t2/index.xhtml\#_idTextAnchor090

Kravchenko, N., \& Pasternak, T. (2020). Institutional eco-pragmatics vs. anthropopragmatics: problems, challenges, research perspectives. Cogito. Multidisciplinary Research Journal, Vol. XII (2), pp. 24-39.

Kravchenko, N., \& Zhykharieva, O. (2020). Signlike Pragmatic Devices: pro et contra. In Kalbu studijos. Studies about Languages, No. 36/2020, pp. 70-84.

Kravchenko, N. (2017). Illocution of direct speech acts via conventional implicature and semantic presupposition / Lege artis. Language yesterday, today, tomorrow. The Journal of University of SS Cyril and Methodius in Trnava. Warsaw: De Gruyter Open, Vol. II (1), p. 128-168.

Kravchenko, N. (2017a). Indirect speech acts' via conversational implicatures and pragmatic presuppositions. Cognition, communication, discourse. International On-line Journal, № 14, pp. 54-66.

Kravchenko, N. (2006). Interactive, genre and conceptual modeling of international legal discourse. Kiev: Referat (in Russian).

Lukashuk, I.I. (1997). The norms of international law in the international normative system. Moscow: Spark (in Russian).

Lyons, J. (1977). Semantics. 2 Vols. London and New York: Cambridge University Press. Retrieved from: Semantics (cambridge.org)

Neubert, Al. (1968). Pragmatic aspects of translation [Pragmatische Aspekte der Übersetzung]. Leipzig: Language and Literature Publisher [Verlag Sprache und Literatur].

Nord, C. (2014). Hurdle jumps. A plea for more courage when translating [Hürden-Sprünge. Ein Plädoyer für mehr Mut beim Übersetzen]. Berlin: BDÜ-Fachverlag.

Nuyts, J. (2016). Analyses of modal meanings. In Jan Nuyts \& Johan van der Auwera (eds.), Oxford handbook of modality and mood, (pp. 31-49). Oxford: Oxford University Press.

Palmer, F.R. (1986). Mood and Modality. Cambridge Textbooks in Linguistics. Cambridge: CUP. Retrieved from: https://www.cambridge.org/core/books/abs/mo od-andmodality/contents/220436A958C21D0A9A96 B1F570495AAC; Mood and Modality - F. R. Palmer - Google Книги Р. 1-80.
Pym, A. (2012). On Translator Ethics. Principles for mediation between cultures. Amsterdam and Philadelphia: Benjamins.

Quirk, R., Greenbaum, S., Leech, G., \& Svartvik, J. (1985). A comprehensive grammar of English language. London: Longman.

Raw, L. (2012). Adaptation, Translation and Transformation. New York: Continuum.

United Nations (1992). Rio Declaration on Environment and Development. Retrieved Aug 18 from: https://www.un.org/en/development/desa/popu lation/migration/generalassembly/docs/globalc ompact/A_CONF.151_26_Vol.I_Declaration.p df

United Nations (1992). United Nations Framework Convention on Climate Change. Retrieved Aug 26 from: https://unfccc.int/resource/docs/convkp/conven g.pdf

United Nations Human Rights (1948). Universal Declaration of Human Rights. Retrieved Sept 18 from: https://www.ohchr.org/EN/UDHR/Documents/ UDHR_Translations/eng.pdf

Sadock, J. (2004). Speech acts. In L. R. Horn \& G. Ward (Eds.), The handbook of pragmatics (pp. 53-73). Malden, Massachusetts: Blackwell Publishing.

Searle, J. (1995). The Construction of Social Reality. New York: Free Press.

Searle, J.R. (1983). Intentionality: An Essay in the Philosophy of Mind. New York: Cambridge University Press.

Searle, J. (1975). A classification of illocutionary acts. Language in Society, 5(1), 1-23.

Searle, J. (1975a). Indirect speech acts. In P. Cole and J. L. Morgan (Eds.), Syntax and semantics, \# 3: Speech acts (pp. 59-82). New York: Academic Press.

Van Leeuwen, T. (1993). Genre and field in critical discourse analysis. Discourse \& Society, 4(2), 193-223.

Venuti, L. (2012). Translation changes everything. London and New York: Routledge.

Vezhbitskaya, A. (2015). Semantic Universals and Language Description. Book on Demand Ltd.

Vinay, J., \& Darbelnet, J. (1972). Comparative stylistics of French and English: translation method. New revised and corrected edition [Stylistique comparée du français et del'anglais: méthode de traduction. Nouvelle édition revue et corrigée].. Paris: Didier

Von Fintel, K. (2006). Modality and language. Encyclopedia of Philosophy. Detroit: MacMillan Reference.

WHO (2003). WHO Framework Convention on Tobacco Control. Retrieved Sept 12 from: http://apps.who.int/iris/bitstream/handle/10665 /42811/9241591013.pdf?sequence $=1$ 